\title{
Trials for Risk Assessment of Japanese Encephalitis Based on Serologic Surveys of Wild Animals
}

\author{
Mika Saito et al.* \\ Department of Microbiology and Oncology, Graduate School of Medicine, \\ University of the Ryukyus, Okinawa \\ Japan
}

\section{Introduction}

Japanese encephalitis (JE) is a severe and acute encephalitis with a high fatality rate, caused by Japanese encephalitis virus (JEV), a mosquito-borne flavivirus of the genus Flavivirus, family Flaviviridae. The JEV serogroup of flaviviruses includes West Nile virus, St. Louis encephalitis virus, and Murray Valley encephalitis virus which also cause encephalitis, though with some clinical variation (Mackenzie et al., 2007). JE is a major public health problem in the Asian region, accounting for more than 16,000 reported cases and 5,000 deaths annually. With the near eradication of poliomyelitis, JE is now the leading cause of childhood viral neurological infection and disability in Asia (Halstead and Jacobson, 2003). Approximately half of all survivors suffer from permanent neurological and/or mental impairments due to the invasion and destruction of cortical neurons and Purkinje cells by the virus (Johnson et al., 1985, Monath, 1986).

Historically, severe epidemics of JE had been reported during the summer season in Japan since the $19^{\text {th }}$ Century and more than 1000 cases were reported annually in the 1960s. With the control of epidemics in Japan and Korea due to changes in agricultural and animal husbandry practices, and in part through vaccination, the number of JE cases markedly

\footnotetext{
* Takashi Ito ${ }^{2}$, Yosuke Amano 3 , Junji Takara ${ }^{4}$, Katsushi Nakata ${ }^{5}$, Shoko Tamanaha ${ }^{5}$ Yuichi Osa ${ }^{6}$, Tomoo Yoshino7, Manabu Onuma ${ }^{8}$, Takashi Kuwana ${ }^{8}$, Go Ogura 5 , Masayuki Tadano ${ }^{1}$, Daiji Endoh ${ }^{9}$ and Mitsuhiko Asakawa ${ }^{7}$ ${ }^{1}$ Department of Microbiology and Oncology, Graduate School of Medicine, University of the Ryukyus, Okinawa, ${ }^{2}$ Nago Zoological and Botanical Gardens, Okinawa,

${ }^{3}$ Nagamine Animal Clinic, Okinawa,

4Naha Veterinary Hospital, Okinawa,

${ }^{5}$ Laboratory of Subtropical Zoology, Faculty of Agriculture, University of the Ryukyus, Okinawa, ${ }^{6}$ Wildlife Section, Nature Conservation Department, Hokkaido Institute of Environmental Sciences, Hokkaido, 'Department of Pathobiology, School of Veterinary Medicine, Rakuno Gakuen University, Hokkaiodo, ${ }^{8}$ Biological Resource Laboratory, Laboratory for Intellectual Fundamentals for Environmental Studies, National Institute for Environmental Studies, Ibaraki, ${ }^{9}$ Department of Veterinary Radiology, School of Veterinary Medicine, Rakuno Gakuen University, Hokkaido Japan
} 
decreased, with less than 10 cases reported annually since the early 1990s (Arai et al., 2008). Meanwhile, JE emerged in Thailand, Vietnam and China in the 1980s. Although the incidence has since declined in these countries, recently the disease has emerged in new areas in Pakistan, and Oceania, particularly Papua New Guinea and northern Australia. The incidence of JE is increasing in countries like Bangladesh, Cambodia, India, Indonesia, Laos, Myanmar, North Korea, and Pakistan (Erlanger et al., 2009). Mackenzie et al (2007)

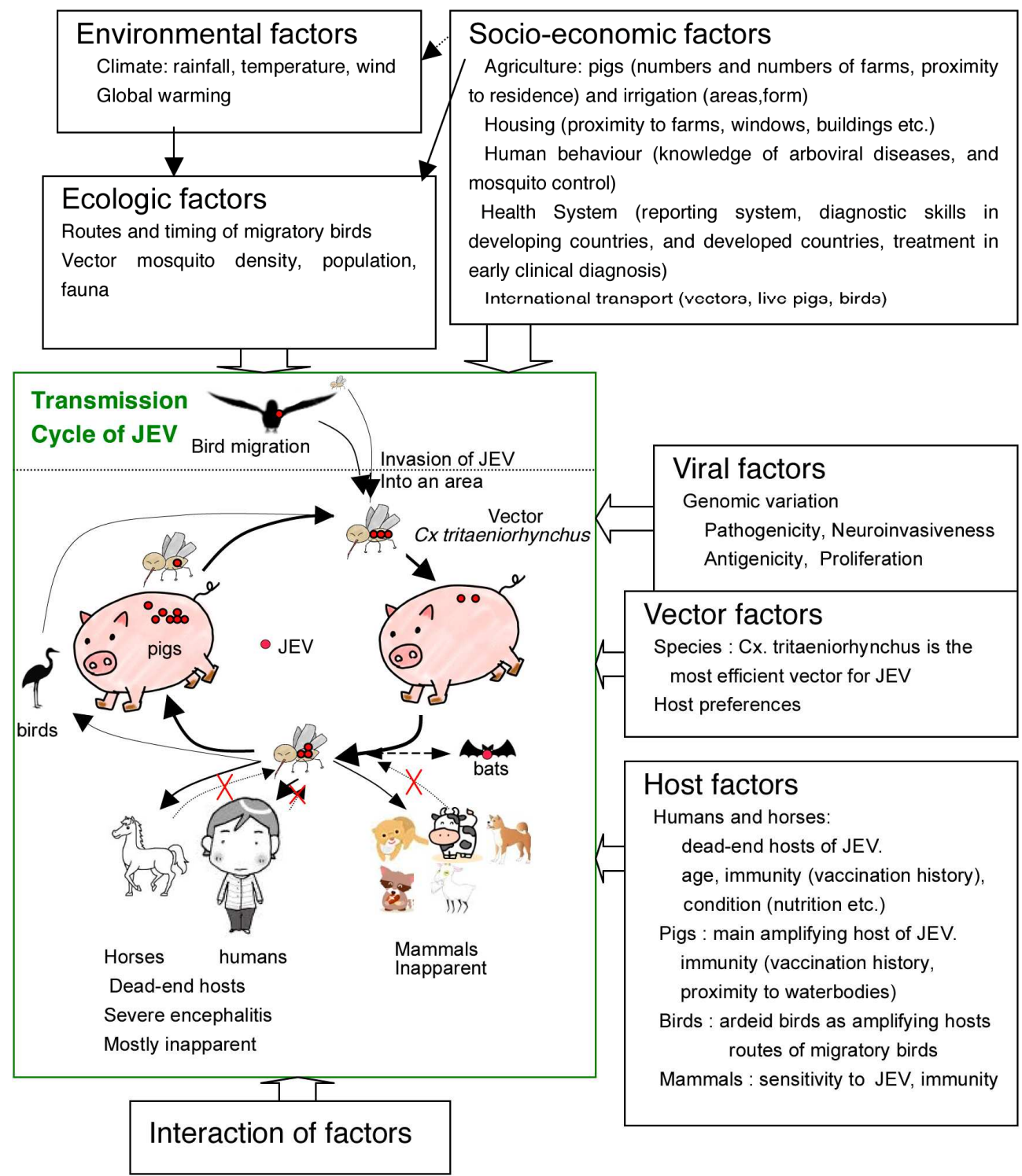

Fig. 1. Transmission cycle of JEV and Risk factors for JE 
attributed this phenomenon to the propensity of JEV to spread and colonize new areas. Genetically, five genotypes (genotype 1, 2, 3, 4 and 5) of JEV had been distributed with geographic segregation (Chen et al. 1992. 1994. Uchil and Satchidanandam 2001). The distribution pattern has changed drastically in the last few decades, with a major shift from genotype 3 to genotype 1 in the 1990s in Japan, as well as Vietnam, China, and Korea (Ma et al., 2003, Chung et al. 1996, Nga et al. 2004.) This indicated that an exotic JEV was introduced into these countries and established a transmission cycle.

JEV is maintained in nature by transmission cycles involving Culex (Cx.) sp. mosquitoes and amplifying hosts. $C x$. tritaeniorhynchus is the most efficient vector, and pigs and certain species of birds, particularly ardeid birds, are the most effective amplifiers. Humans and horses are incidental, known as dead-end hosts, and most infected mammals do not develop sufficient levels of viremia to infect mosquitoes. As JEV has a wide range of hosts, environmental changes such as global warming, and economic development including irrigation and animal husbandry practices influence its distribution and occurrence.

At present, no specific treatment for JE is available, and the efficacy of ongoing vaccines against various genotypes found in Asia is also controversial. Therefore, surveillance and risk assessment using an interdisciplinary approach are required for the control of JE, and also other flaviviral infections.

Risks of JE infection closely relate to the transmission cycles of JEV, and many factors involved there in. Factors worth considering when assessing risks are described briefly in Figure 1. Risks of JE occurrence in humans relate to both host and viral factors. The ratio of apparent to inapparent JE infections in humans in estimated at 1:200 to 1:1000. The frequency of exposure through infected mosquitoes becomes high in areas where JE is epidemic. Migratory birds, wind-blown vectors, and the transport of vectors and animals would be determinants of the invasion by JEV of new areas.

In this study, a serologic survey of domestic and migratory wild mammals and wild birds was conducted in Hokkaido and Okinawa, Japan, in order to assess risks for JE in humans. The necessity of assessing risks based on serosurveys of wild animals is discussed.

\section{Trials for risk assessment of Japanese encephalitis - a serosurvey of wild animals in Japan}

\subsection{Study design}

\subsubsection{Study areas}

A seroepidemiologic study of wild animals was conducted in Hokkaido, northern Japan, about $850 \mathrm{~km}$ from Tokyo, and on Okinawa Island; a small subtropical island, about 2.000 $\mathrm{km}$ southwest of Tokyo (Figure 2).

\subsubsection{Collection of serum samples from wild mammals}

Alien mammals such as the raccoon Procyon lotor in Hokkaido and Honshu, and the mongoose Herpestes auropunctatus on Okinawa island threaten ecological destruction as predators of endangered species, and government projects to control their population were conducted with the permission of the Ministry of the Environment, Japan. Sera were obtained from 45 raccoons captured in central Hokkaido in 2005, and Mongooses captured in Okinawa between 2001 and 2005 (Saito et al, 2009a). Two serum samples were obtained 
from injured flying foxes, Pteropus dasymallus inopinatus Kuroda, rescued on Okinawa in 2007 and 2008. The isolation of viruses from all serum samples was attempted without success.

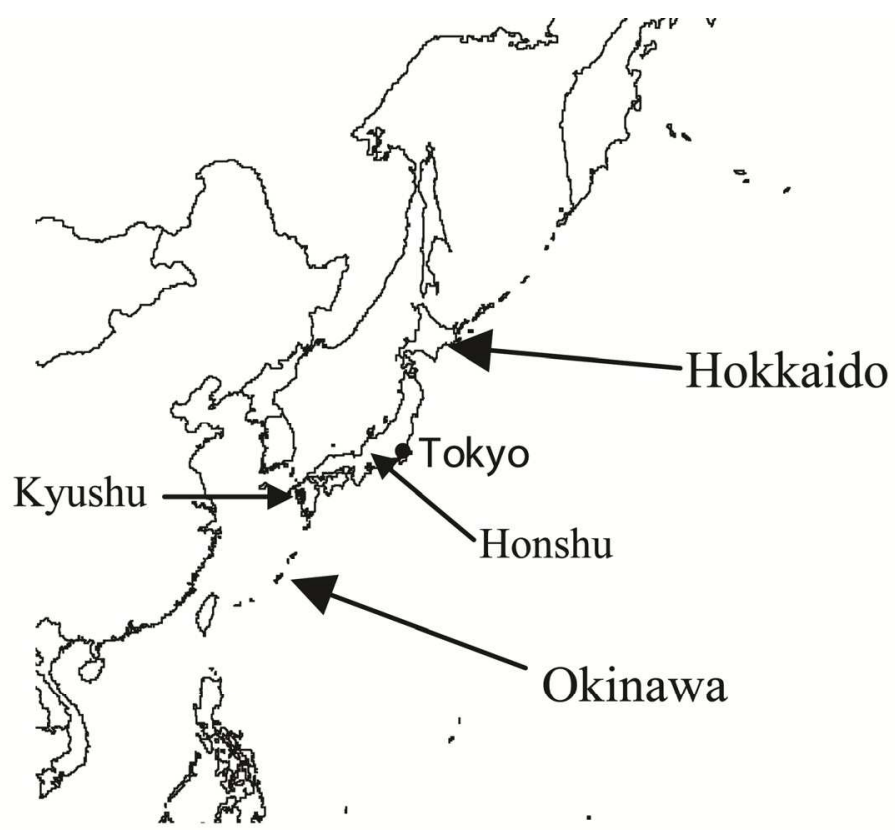

Fig. 2. Location of study areas

\subsubsection{Collection of serum samples from wild birds}

A total of 50 wild ducks were captured in eastern Hokkaido in 2008, with permission from the Ministry of the Environment, Japan. Eight Spot-billed Ducks (Anas poecilorhyncha), 17 Mallards (A. platyhynchos), 1 Eurasian Wigeon (A. penelope), and 24 Northern Pintails (A. acuta) were subjected to a serosurvey. Spot-billed Ducks are recognized as migrant breeders, Mallards as residents breeders or wondering birds, and Eurasian Wigeons and Northern Pintails as winter visitors in Hokkaido.

A total of 72 injured birds, mostly from traffic-related accidents, rescued in animal hospital and zoos as wildlife relief facilities on Okinawa from 2007 to 2009, were subjected to a serosurvey. The order, family, and species of the birds are listed in Table 1. Eleven orders, 17 familiies, and 28 species were collected. Roughly, the birds were classified seasonally, seven individuals (one species) as migrant (summer) breeders, 29 (13 species) as winter vistors, 34 (12 species) as resident breeders, and 2 (2 species) as wondering breeders in Okinawa. Brains, livers, hearts, and spleens were sampled from dead bodies. The isolation of viruses from all samples was attempted without success.

\subsubsection{Positive and negative control sera for birds}

To conduct the serologic survey of wild birds, negative and positive control sera were used. As maternal antibody levels declined 2 weeks after hatching in chickens, and 3 weeks after 
hatching in ducks, sera from 10 chicks reared for 2 weeks after hatching in a cage without mosquito bites, and 70 Aigamo juvenile ducks, a cross between wild ducks (A. platyrhynchos) and domestic ducks (A. platyrynchos var. domesticus), reared for 50 days after hatching in a room until early May, not the breeding season for mosquitoes, 2008, in Hokkaido, were used as negative control. Positive sera for JE were produced in chickens by immunization with an inactivated JE vaccine for animals (Kyoto Biken, Japan) three times weekly, starting from 2 weeks of age, and bleeding the animals 2 weeks after the last immunization. Serum samples from 7 Aigamo ducks infected by West Nile virus (NY-99 strain) were provided and used as reference sera for flavivirus infection (Shirafuji et al., 2009).

\begin{tabular}{|c|c|c|c|c|c|}
\hline Order & Family & species & English name & $\mathrm{n}(+)^{*}$ & seasonal \\
\hline \multirow[t]{2}{*}{ Anseriformes } & Anatidae & Aythya fuligula & Tufted duck & $1(1)$ & winter \\
\hline & & Anas poecilorhyncha & Spotbilled duck & $1(0)$ & residents \\
\hline Caraciformes & Alcedinidae & Halcyon coromanda & Ruddy Kingfisher & $7(0)$ & summer \\
\hline \multirow[t]{5}{*}{ Pelecaniformes } & Ardeidae & Bubulcus ibis & Cattle Egret & $2(2)$ & winter \\
\hline & & Egretta alba & Great Egret & $2(1)$ & winter \\
\hline & & Egretta intermedia & Intermediate Egret & $3(0)$ & winter \\
\hline & & Ardea cinerea & Grey heron & $4(1)$ & winter \\
\hline & & Egretta sacra & Pacific reef egret & $1(0)$ & residents \\
\hline \multirow[t]{3}{*}{ Accipitriformes } & Accipitridae & Butastur indicus & $\begin{array}{c}\text { Grey-faced } \\
\text { buzzard }\end{array}$ & $7(0)$ & winter \\
\hline & & Accipiter gularis & $\begin{array}{c}\text { Japanese sparrow } \\
\text { hawk }\end{array}$ & $1(1)$ & residents \\
\hline & Pandionidae & Pandion haliaetus & Osprey & $1(0)$ & winter \\
\hline Falconiformes & Falconidae & Falco peregrinus & Peregrine Falcon & $1(0)$ & winter \\
\hline $\begin{array}{c}\text { Procellariiforme } \\
\text { s } \\
\end{array}$ & Procellariidae & Puffinus pacificus & $\begin{array}{l}\text { Wedge-tailed } \\
\text { shearwater }\end{array}$ & $1(0)$ & wondering \\
\hline \multirow[t]{3}{*}{ Columbiformes } & Columbidae & Streptopelia orientalis & $\begin{array}{l}\text { Eastern turtle } \\
\text { dove }\end{array}$ & $5(2)$ & residents \\
\hline & & Sphenurus formosae & $\begin{array}{l}\text { Whistling Green- } \\
\text { pigeon }\end{array}$ & $5(0)$ & residents \\
\hline & & Columba livia & Rock dove & $1(0)$ & residents \\
\hline \multirow[t]{4}{*}{ Passeriformes } & Turdidae & Turdus pallidus & Pale Thrush & $3(0)$ & winter \\
\hline & & Monticola solitarius & Blue Rock Thrush & $1(0)$ & residents \\
\hline & Hirundinidae & Hirundo tahitica & Pacific swallow & $1(0)$ & residents \\
\hline & Corvidae & $\begin{array}{c}\text { Corvus } \\
\text { macrorhynchos }\end{array}$ & Jungle Crow & $3(0)$ & residents \\
\hline \multirow[t]{2}{*}{ Stringiformes } & Stringidae & Ninox scutulata & Brown hawk owl & $11(2)$ & residents \\
\hline & & Otus lempiji & Sunda Scops-owl & $3(0)$ & residents \\
\hline Charadriiformes & Laroidae & Larus crassirostris & Black-tailed gull & $2(0)$ & winter \\
\hline
\end{tabular}




\begin{tabular}{|c|c|c|c|c|}
\hline \multirow[t]{4}{*}{ Order } & Family & species & English name & $\mathrm{n}(+)^{*} \quad$ seasonal \\
\hline & Charadriidae & Vanellus vanellus & " Northern lapwing & winter \\
\hline & Scolopacidae $\Lambda$ & Numenius phaeopus & Whimbrel & winter \\
\hline & $\begin{array}{l}\text { Stercoradriid } \\
\text { ae }\end{array}$ & $\begin{array}{l}\text { Stercorarius } \\
\text { longicaudus }\end{array}$ & Long-tailed jaeger & $1(0)$ wondering \\
\hline \multirow[t]{2}{*}{ Gruiformes } & Rallidae & Gallinula chloropus & $\begin{array}{l}\text { Common } \\
\text { Moorhen }\end{array}$ & residents \\
\hline & & Felica atra & Coot & winter \\
\hline \multicolumn{3}{|l|}{$\begin{array}{c}\text { Total (number of } \\
\text { positive) }\end{array}$} & & $\begin{array}{c}72 \\
(10)\end{array}$ \\
\hline \multicolumn{5}{|c|}{$\begin{array}{l}{ }^{*} \mathrm{n}=\text { number of rescued birds. Values in parenthesis are number of JEV antibody-positive birds } \\
\text { Table } 1 \text {. The list of injured birds rescued in Okinawa and the number of birds positive for } \\
\text { JEV antibodies }\end{array}$} \\
\hline & $\begin{array}{l}\text { Chicken } \\
\text { Negative } \\
\text { Control }(n=7)\end{array}$ & $\begin{array}{l}\text { Chicken } \\
\text { JE vaccinated } \\
(n=4)\end{array}$ & $\begin{array}{l}\text { Aigamo duck } \\
\text { Negative } \\
\text { Control }(n=70)\end{array}$ & $\begin{array}{l}\text { Aigamo duck } \\
\text { WNV infected } \\
\quad(n=7)\end{array}$ \\
\hline $\mathrm{FRNT}_{50}$ & $0 \%$ & $100 \%$ & $55.7 \%$ & $100 \%$ \\
\hline $\mathrm{FRNT}_{90}$ & $0 \%$ & $100 \%$ & $1.4 \%$ & $85.7 \%$ \\
\hline
\end{tabular}

Table 2. Neutralization antibody titers against JEV Nakayama with different stringencies

\subsubsection{Serologic survey}

Fifty percent focus reduction neutralization tests $\left(\mathrm{FRNT}_{50}\right)$ were conducted to measure neutralizing antibody titers against JEV strains, Nakayama (prototype strain) and Beijing-1 (laboratory strain), for mammals as described previously (Saito et al., 2009a). Ninety percent focus reduction neutralization tests $\left(\mathrm{FRNT}_{90}\right)$ were employed to measure neutralizing antibody titers against the Nakayama strain for wild birds. The testing was done on BHK-21 cells in 96-well microplates with an immuno-staining method as described previously (Saito et al., 2007).

\subsection{Results}

\subsubsection{Serosurvey of wild mammals}

A single sample from 45 raccoons (2.2\%) in Hokkaido had antibody titers of 70 and 40 against the Nakayama and Beijing-1 strains, respectively.

Previously obtained serologic data, showing that $35.4 \%(85 / 240)$ of mongooses had antibodies for JEV (Saito et al., 2009a), was re-analyzed by GIS on different scales (Figure 4). The analysis on a small scale showed barns, bodies of water and rive paddies to be near the capture points of mongooses with high titers of JE antibody.

Both of the flying foxes captured in Okinawa had antibodies against Nakayama, with titers of 17 and 14, respectively. 


\subsubsection{Serosurvey of wild birds}

To evaluate the reliability of testing, both $\mathrm{FRNT}_{50}$ and $\mathrm{FRNT}_{90}$ at different stringencies, were conducted on negative and positive control (JE immunized and WNV infected) samples of chickens and Aigamo ducks (Table 2) (Buckley et al, 2003). Non-specific reactions were observed at a high rate $(55.7 \%)$ among negative control ducks, by $\mathrm{FRNT}_{50}$. Even by $\mathrm{FRNT}_{90}$, a single duck showed a non-specific reaction, although the titer was low as 10. Serologic tests using Negative controls of chickens and JE-vaccinated chickens clearly showed all samples to be negative and all to be positive by $\mathrm{FRNT}_{50}$ and $\mathrm{FRNT}_{90}$. WNV-infected ducks as reference showed positive for JE antibody by both stringencies of test, except a single sample by FRNT $_{90}$. Given the results, FRNT90 against JEV Nakayama was employed for the seroepidemiologic survey of wild birds.

Among 50 serum samples from 4 species of ducks; spot-billed ducks, mallards, northern pintails and Eurasian wigeons, in Hokkaido, only a single sample from spot-billed ducks $(2 \%)$ recognized as migrant breeders had JE antibodies (Figure 3 ).
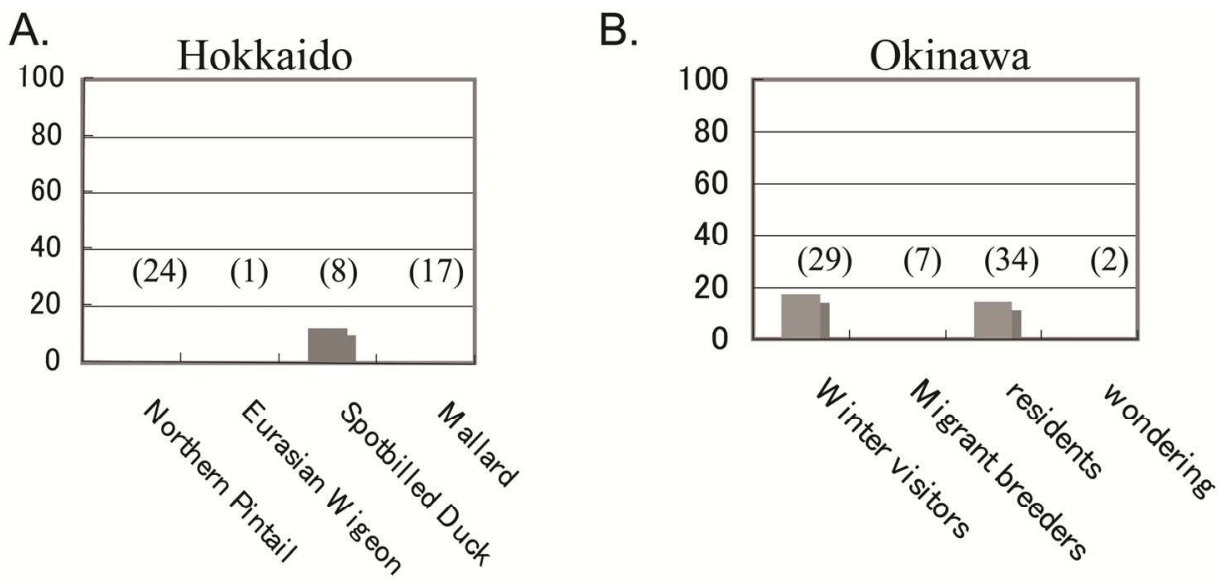

Fig. 3. Antibody-positive rates of ducks captured in Hokkaido (A) and injured birds rescued in Okinawa (B) against the Nakayama strain. Northern Pintails and Eurasian Wigeons are recognized as winter visitors, Spotbilled Ducks as migrant breeders, and Mallards as residents, and partly wonderers. Values in parentheses show numbers of bird species or seasonal groups

A total of $10(14.2 \%)$ sera of wild birds in Okinawa had JE antibodies. Five (2 Cattle Egrets, 1 Grey heron, 1 Great Egret, and 1 Tufted duck) were from 29 winter visitors and 5 (2 Brown hawk owls, 2 Eastern turtle doves, and 1 Japanese sparrow hawk) from 34 resident breeders. Four of the five positive sera in winter visitors were from ardeid birds. None of the migrant breeders had antibodies (Table 1 and Figure 3).

\section{Discussion}

A seroepidemiologic study was conducted on wild mammals and wild birds in Hokkaido and Okinawa, Japan, and risks for JEV infection and JEV invasion were evaluated by 
knowing local transmission activity and the seroprevalence of migratory species, respectively. JEV activity in Hokkaido is known to be low, as demonstrated by serosurveys of pigs (Infectious Disease Surveillance Center), although focal outbreaks occured in pigs in the 1980s (Takashima et al. 1988). In Okinawa, high JEV transmission rates have been demonstrated by serosurveys of pigs indicating the longest JEV active season in Japan, and the virus has been isolated even in winter (Ura, 1976, Tadano et al. 1994, Infectious Disease Surveillance Center). About $100 \mathrm{JE}$ cases were reported with fluctuations until the mid 1960s. The last reported case was in 1998. Seroconversion in pigs was used for JE surveillance for many years, nationwide in Japan, and thus is generally accepted as reflecting the JEV transmission rate in an area.

We reported a serosurvey of mongooses in Okinawa, valuable for understanding the local transmission activity of JEV in nature. By using mongooses under control projects, it is possible to analyze capture points and antibody titers, enabling estimates of high transmission areas on a small scale (Figure 4A) (Saito et al., 2009a). The environmental condition at the capture point for animals with high antibody titers were suitable for the transmission of JEV, i.e. rive fields and bodies of water for the breeding of vector mosquitoes and barns for pigs as an amplifier of JEV (Figure 4B). However, mongooses mostly inhabit only the Okinawa and Amami islands in Japan. By contrast, raccoons, another alien species is distributed over a wide range in Japan, though not in Okinawa. In this study, a serosurvey of raccoons was conducted in Hokkaido, showing low positive rates with only a single sample having JE antibodies, thus implying low transmission of JEV there. Ohno et al (2009) also conducted a comparative serosurvey of raccoons in Hokkaido and in the Kinki area of western Japan, showing a high prevalence of JEV in western and low prevalence in northern areas. Thus, the animal appears to be a good sentinel for JEV infection. In this study, the suitability of risk assessments with serosurveys of alien animals under control projects, together with fundamental data analysis is indicated.

We also conducted a serosurvey of migratory species. It was reported that flying foxes have a potential role in the transmission cycle and dispersal of JEV (van den Hurk AF et al, 2009). Antibodies against JEV with low titers were observed in both flying foxes caught in Okinawa, a species that can fly short distances within the island or to nearby islands. Flying foxes might play a role in the dispersal of JEV on the island.

Interestingly, in this serosurvey of wild birds, all of the positive ducks collected in Hokkaido, 2008 were Spotbilled ducks, a migrant breeder in Hokkaido, and seemed to have been infected in the south (Saito et al, 2009b). Results from our studies of raccoons and wild ducks showed low transmission rates of JEV in Hokkaido, consistent with those for pigs and other species.

The yearly sero-conversion of JEV in pigs starts in Okinawa, and moves to the north. This phenomenon may be caused by the migration or hibernation of JEV. The migratory flyways of migrant breeders such as the Ruddy Kingfisher correlate with this movement, from south, Australia, to north, Siberia, through Okinawa, and mainland Japan. However, no migrant breeder tested negative for the JEV antibody in this study. Nabeshima et al (2009) described that JEV is frequently introduced into Japan from Southeast Asia and continental east Asia, based on a molecular epidemiologic study and chronological order. Okinawan genotype 1 strains are closely related to strains from other parts of Japan, Korea and China, but different from Australian strains (Saito et al., 2007). Recently genotype 1 with the same subcluster as Kyushu and Shanghai appeared in Taiwan, in 2007, approximately 10 years after their first 
appearance in China, Korea, and Japan (Huang et al, 2010). Thus, the direction of JEV's introduction seemed to be from north to south. Five winter visitors with antibodies were observed, 2 Cattle Egrets, 1 Grey Heron, 1 Great Egret and 1 Tufted duck. They are thought to have been infected in the north, not in Okinawa, because of seasonal characteristics. Ardeid birds, Egrets and Herons are known amplifiers of JEV and involved in JEV invasion (Buescher EL et al, 1959). From the results of this study, together with molecular epidemiologic studies, JEV is suggested to have been introduced into Okinawa from Honshu, and Kyushu, possibly by a winter visitor such as ardeid birds. The flyways of most ardeid birds remain unknown. Their elucidation and continuous epidemiologic and virologic studies will provide important information for evaluating risks of JEV invasion. Migratory birds are one of the determinants with which to assess invasive viruses like not only JEV, but also flaviviruses with a similar epidemiology.
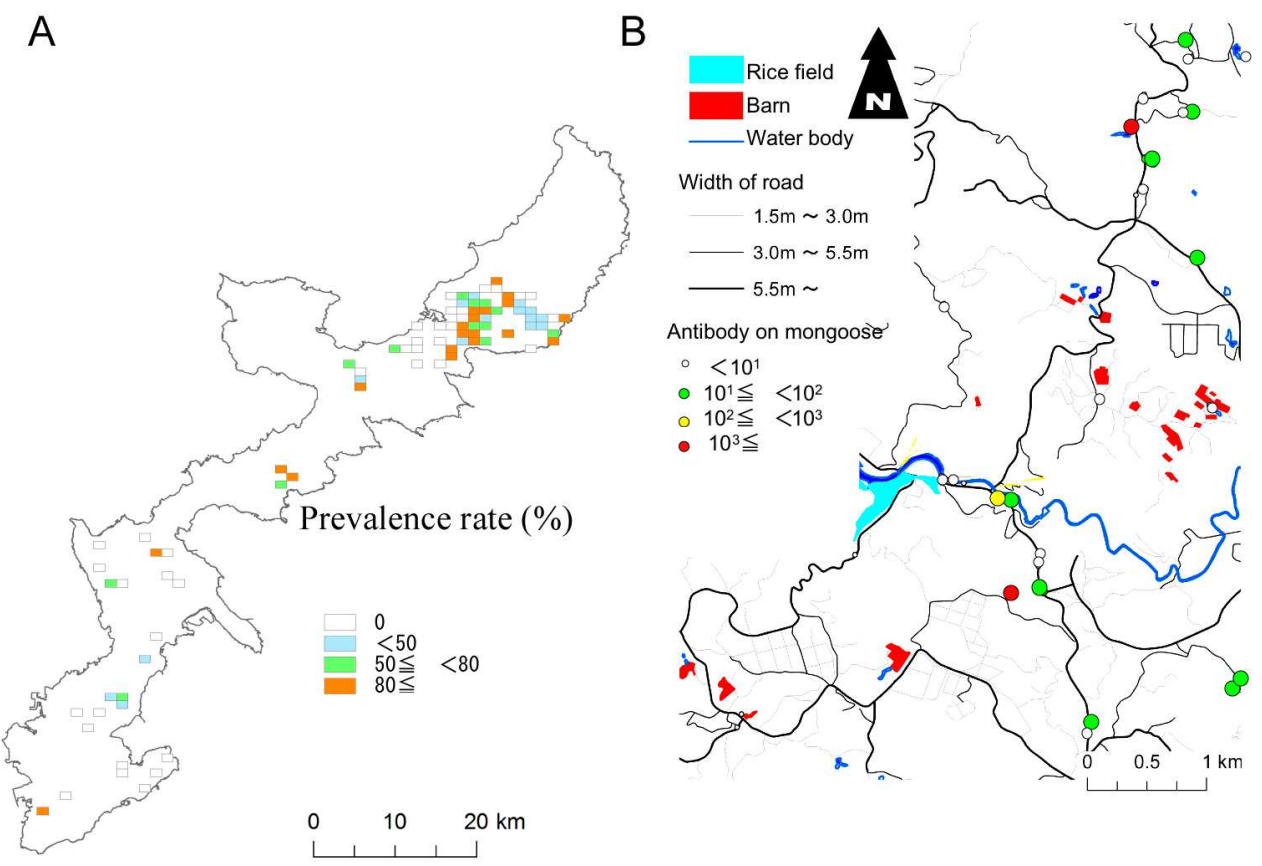

Fig. 4. Map of Okinawa Island used for the GIS analysis using mesh with prevalence rates of JE antibody in mongooses (ref. Saito et al, 2009a) (A). Map of high prevalence areas with the location of farms (B). Dots show capture points and the JE antibody titer

JEV antibodies were detected in 14.3 \% (5/35) of resident breeders in Okinawa between 2007 and 2009, a relatively low rate. This however may be due to the inclusion of data from a variety of species and sizes, differing in sensitivity and mosquito preference. In Okinawa, serosurveys of pigs have showed that seroprevalence has gradually decreased since the mid 2000s and was less than $20 \%$ in 2009 and 2010, which indicated that low transmission activity (Infectious Disease Surveillance Center) might correlate with seroprevalence in resident breeders and mongooses. 
The Ministry of Health, Labour and Welfare in Japan discontinued the recommendation for JE vaccinations due to adverse events for 5 years from 2005. During this period, no epidemic of JE occurred in Japan, and no cases were reported in Okinawa either. Risk assessments for JE should be strengthened to evaluate the quick and drastic changes in natural transmission that might be occurring in Okinawa with an interdisciplinary approach, including studies of mosquitoes, serosurveys of people, domestic and wild animals, and vaccine evaluation. A reconsideration of JE control is required in step with recent changes.

\section{Conclusion}

The distribution and occurrence of JE are changing due to environmental influences. Therefore, risk assessment and surveillance are important for controlling JE. Serosurveys of pigs as amplifiers are the predominant means of assessing risks of JEV infection, and also sustainable. Wild mammals such as raccoons and mongooses are valuable sentinels for assessing natural transmission, and strengthen the notion of surveillance using pigs, while control programs for alien mammals provide the opportunity for a detailed geographic analysis of JEV transmission. Virologic and serologic surveys of wild birds, particularly ardeid birds as possible amplifiers, and bats should be sustained to assess risks of JEV invasion. Furthermore, they may reveal the mechanisms by which the distribution of JEV is expanding.

\section{Acknowledgements}

The authors are grateful to Dr. Takashi Nagamine for his cooperation and advice, the staff of the Department of Agriculture, University of the Ryukyus for sampling wild birds, and the staff of Rakuno Gakuen University for sampling raccoons and wild birds in Hokkaido. They also express thanks to Dr. Hiroaki Shirafuji, for providing control sera from Aigamo ducks.

\section{Disclosure statements}

This study was supported by Grant-in Aid for Exploratory Research (No. 16659121 and No. 19658115) and Scientific Research (No. 20380163 and No. 23510030), from the Ministry of Education, Culture, Sports, Science and Technology of Japan, and by the Global Environment Research Fund of the Ministry of the Environment, Japan, F-3 and F-9.

\section{References}

Arai S, Matsunaga Y, Takasaki T, Tanaka-Taya K, Taniguchi K, Okabe N, Kurane I, Vaccine Preventable Disease Surveillanve Program of Japan. 2008. Japanese Encephalitis: Surveillance and Elimination Effort in Japan from 1982 to 2004. Jpn J Infect Dis. 61, 333-338

Buckley A, Dawson A, Moss SR, Hinsley SA. 2003. Serological evidence of West Nile virus, Usutsu virus and Sindbis virus infection of birds in the UK. J Gen Virol, 8, 2807-2817

Buescher EL, Scherer WF, McClure HE, Moyer JT, Rosenberg MZ, Yoshi M, Okada Y. 1959. Ecologic studies of Japanese encephalitis in Japan. IV. Avian Infection. Am J Trop Med Hyg, 8, 689-697 
Chen WR, Rico-Hesse R. \& Tesh RB 1992. A new genotype of Japanese encephalitisvirus from Indonesia. Am J Trop Med Hyg 47, 61-69

Chen WT, Tesh RB \& Rico-Hesse R. 1990. Genetic variation of Japanese encephalitis virus in nature. J Gen Virol 71, 2915-2922

Chung YJ, Nam JH, Ban SJ, and Cho HW. 1996. Antigenic and genetic analysis of Japanese encephalitis viruses isolated from Korea. Am J Trop Med Hyg. 55, 91-97.

Erlanger, TE, Weiss S, Keiser J, Utzinger J, and Wiedenmayer, K. 2009, Past, present, and future of Japanese encephalitis. Emerging Infectious Diseases 15, 1-7

Halstead SB and Jacobson J, 2003, Japanese encephalitis. Adv Virus Res 61, 103-138

Huang JH, Lin TH, Teng HJ, Su CL, Tsai KH, Lu LC, Lin C, Yang CF, Chang SF, Liao TL, Yu SK, Cheng CH, Chang MC, Hu HC, Chu PR. 2010. Molecular Epidemiology of Japanese encephalitis virus, Taiwan. Emerging Infectious Diseases, 16, 876-878

Infectious Disease Serveillance Center, http://idsc.nih.go.jp/yosoku/JE/JEmap2009-E.html

Johnson, RT, Burke, DS, Elwell M, Leake CJ, Nisalak A, Hoke CH, and Lorsomrudee, W. 1985. Japanese encephalitis: immunocytochemical studies of viral antigen and inflammatory cells in fatal cases. Annu. Neurol. 18, 567-573

Ma SP, Yoshida Y, Nakino Y, Tadano M, Ono T, and Ogawa M. 2003. A major genotype of Japanese encephalitis virus currently circulating in Japan. Am J Trop Med Hyg 69, 151-154.

Mackenzie JS, Williams DT, and Smith DW. 2007. Japanese Encephalitis Virus: The Geographic Distribution, Incidence, and Spread of a Virus with a Propensity to Emerge in New Area. In Emerging Virus in Human Population. pp. 201-268. Edited by T. Tobaor. Elsevir press.

Monath TP. 1986. Pathobiology of the flaviviruses, p.375-440. In Schlesinger, S., and Schlesinger MF. (eds), The Togaviridae and Flaviviridae, Avademic Press, New York.

Nabeshima T, Loan HTK, Inoue S, Sumiyoshi M, Haruta Y, Nga PT, Huoung VTQ, Parquet MC, Hasebe F, Morita, K. 2009. Evidence of frequent introductions of Japanese encephalitis virus from south-east Asia and continental east Asia to Japan. J Gen Virol, 90, 827-832

Nga PT, Parquet MC, Cuong VD, Ma SP, Hasebe F, Inoue S, Makino Y, Takagi M, Nam VS and Morita K. 2004. Shift in Japanese encephalitis virus (JEV) genotype circulating in northern Vietnam: implications for frequent introductions of JEV from Southeast Asia to East Asia. J Gen Virol 85, 1625-31.

Ohno Y, Sato H, Suzuki K, Yokoyama M, Uni S, Shibasaki T, Sashika M, Inokuma H, Kai K, Maeda K. 2009. Detection of antibodies against Japanese encephalitis virus in raccoons, raccoon dogs and wild boars in Japan. J Vet Med Sci 71, 1035-1039

Saito M, Nakata K, Nishijima T, Yamashita, K, Saito A, Ogura G, 2009a, Proposal for Japanese encephalitis surveillance using captured invasive mongooses under an eradication project on Okinawa Island, Japan. Vector Borne Zoonotic Dis. 9, 259-266

Saito M, Osa Y, Asakawa M, 2009b, Antibodies to flaviviruses in wild ducks captured in Hokkaido, Japan: Risk assessment of Invasive flaviviruses, Vector Borne Zoonotic Dis. 9, 253-258

Saito M, Taira K, Itokazu K, Mori N, 2007, Recent change of the antigenicity and genotype of Japanese encephalitis viruses distribute on Okinawa Island, Japan. Am J Trop Med Hyg. 77, 737-746 
Shirafuji H, Kanehira K, Kubo M, Shibahara T, Kamio T. 2009, Experimental West Nile virs infection in Aigamo ducks, a cross between wild ducks (Anas platyrhynchos) and domestic ducks (Anas platyrhynchos var. domesticus), Avian Diseases, 53, 239-244

Tadano M, Kanemura K, Hasegawa H, Makino Y, Fukunaga T. 1994. Epidemiological and ecological studies of Japanese encephalitis in Okinawa, subtropical area in Japan. I. Investigations on antibody levels to Japanese encephalitis virus in swine sera and vector mosquito in Okinawa, Miyako and Ishigaki islands. Microbiol Immunol, 38, 117-122

Takashima I, Watanabe T, Ouchi N, Hashimoto N. 1988. Ecological studies of Japanese encephalitis virus in Hokkaido: interepidemic outbreaks of swine abortion and evidence for the virus to overwinter locally. J Med Entomol. 26, 454-458

Uchil PD and Satchidanandam V. 2001. Phylogenetic analysis of Japanese encephalitis virus: envelope gene based analysis reveals a fifth genotype, geographic clustering, and multiple introductions of the virus into the Indian subcontinent. Am J Trop Med Hyg $65,242-51$.

Ura M. 1976 Ecology of Japanese encephalitis virus in Okinawa, Japan. I. The investigation on pig and mosquito infection of the virus in Okinawa Island from 1966 to 1976. Tropical medicine 18151

van den Hurk AF, Smith CS, Field HE, Smith IL, Northill JA, Taylor CT, Jansen CC, Smith GA, Mackenzie JS. 2009. Transmission of Japanese encephalitis virus from the Black Flying Fox, Pteropus alecto, to Culex annulirostris mosquitoes, despite the absence of detectable viremia. Am J Trop Med Hyg. 81, 457-462. 


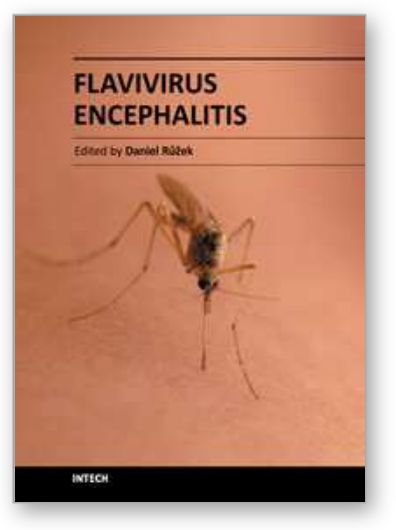

\author{
Flavivirus Encephalitis \\ Edited by Dr. Daniel Ruzek
}

ISBN 978-953-307-669-0

Hard cover, 478 pages

Publisher InTech

Published online 30, September, 2011

Published in print edition September, 2011

Encephalitis is an inflammation of the brain tissue associated with clinical evidence of brain dysfunction. The disease is of high public health importance worldwide due to its high morbidity and mortality. Flaviviruses, such as tick-borne encephalitis virus, Japanese encephalitis virus, Murray Valley encephalitis virus, or St. Louis encephalitis virus, represent important causative agents of encephalitis in humans in various parts of the world. The book Flavivirus Encephalitis provides the most recent information about selected aspects associated with encephalitic flaviviruses. The book contains chapters that cover a wide spectrum of subjects including flavivirus biology, virus-host interactions, role of vectors in disease epidemiology, neurological dengue, and West Nile encephalitis. Special attention is paid to tick-borne encephalitis and Japanese encephalitis viruses. The book uniquely combines up-to-date reviews with cutting-edge original research data, and provides a condensed source of information for clinicians, virologists, pathologists, immunologists, as well as for students of medicine or life sciences.

\title{
How to reference
}

In order to correctly reference this scholarly work, feel free to copy and paste the following:

Mika Saito, Takashi Ito, Yosuke Amano, Junji Takara, Katsushi Nakata, Shoko Tamanaha, Yuichi Osa, Tomoo Yoshino, Manabu Onuma, Takashi Kuwana, Go Ogura, Masayuki Tadano, Daiji Endoh and Mitsuhiko Asakawa (2011). Trials for Risk Assessment of Japanese Encephalitis Based on Serologic Surveys of Wild Animals, Flavivirus Encephalitis, Dr. Daniel Ruzek (Ed.), ISBN: 978-953-307-669-0, InTech, Available from: http://www.intechopen.com/books/flavivirus-encephalitis/trials-for-risk-assessment-of-japanese-encephalitisbased-on-serologic-surveys-of-wild-animals

\section{INTECH}

open science | open minds

\section{InTech Europe}

University Campus STeP Ri

Slavka Krautzeka 83/A

51000 Rijeka, Croatia

Phone: +385 (51) 770447

Fax: +385 (51) 686166

www.intechopen.com

\section{InTech China}

Unit 405, Office Block, Hotel Equatorial Shanghai

No.65, Yan An Road (West), Shanghai, 200040, China

中国上海市延安西路65号上海国际贵都大饭店办公楼 405 单元

Phone: +86-21-62489820

Fax: +86-21-62489821 
(C) 2011 The Author(s). Licensee IntechOpen. This chapter is distributed under the terms of the Creative Commons Attribution-NonCommercialShareAlike-3.0 License, which permits use, distribution and reproduction for non-commercial purposes, provided the original is properly cited and derivative works building on this content are distributed under the same license. 